\title{
Prevalence of Extended Spectrum Beta-Lactamases among Escherichia coli and Klebsiella spp isolates in Manipal Teaching Hospital, Pokhara, Nepal
}

\author{
Shristi Raut ${ }^{1}$, Shishir Gokhale², Bipin Adhikari ${ }^{3}$ \\ ${ }^{1}$ Microbiology Department, Lumbini Medical College, Palpa, Nepal \\ ${ }^{2}$ Professor and HOD, Microbiology Department, Manipal College of Medical Sciences, Pokhara, Nepal \\ ${ }^{3}$ Consultant Physicians, Tropical Health Care and Research Foundation, Kathmandu, Nepal
}

\begin{abstract}
Objective: To isolate, identify and phenotypically characterize extended spectrum beta-lactamase (ESBL)-producing Escherichia coli and Klebsiella spp in Manipal Teaching Hospital.

Methods: Cross sectional study was conducted among E. coli and Klebsiella spp recovered from patients' various samples to establish the prevalence of organisms producing ESBL in Manipal Teaching Hospital, Pokhara, Nepal between October 2011 and April 2012. ESBL production was detected by Clinical laboratory Standards Institute (CLSI) recommendations.

Results: E. coli $(\mathrm{n}=285)$ and Klebsiella spp $(\mathrm{n}=55)$ were isolated from various clinical samples. The specimens were urine $255(75 \%)$, blood $18(5.3 \%)$, pus 48 (14.1\%), sputum $17(5.1 \%)$, and body fluid $2(0.6 \%)$. Seventy six (22.4\%) were ESBL producing organisms by phenotypic confirmatory test with double disk diffusion method. ESBL group of organisms showed $100 \%$ resistance to ampicillin and cefotaxime. All the organisms in this study were $100 \%$ sensitive to imipenem and $95.6 \%$ sensitive to cefoperazone+sulbactam combination. ESBL producing isolates showed high rate of resistance to ciprofloxacin $(90.7 \%)$, ceftriaxone $(89.4 \%)$, ceftazidime (89.4\%), cotrimoxazole $(90.4 \%)$ and norfloxacin $(88.1 \%)$ as compared to non-ESBL group.

Conclusion: ESBL producing E. coli and Klebsiella spp showed high prevalence in Nepal. Routine laboratory testing for ESBL in Nepalese hospitals is needed in order to optimize antibiotic management and reduce the risk of spread of infections caused by ESBL producers. J Microbiol Infect Dis 2015;5(2): 69-75
\end{abstract}

Key words: Extended spectrum beta-lactamase, ESBL, E. coli, Klebsiella spp, Prevalence, Nepal

\section{Bir Nepal hastanesinde Escherichia coli and Klebsiella spp. türlerinde genişlemiş spektrumlu beta-laktamaz sıklığı}

\section{ÖZET}

Amaç: Manipal Eğitim Hastanesi'nde genişlemiş spektrumlu beta-laktamaz (GSBL) üreten Escherichia coli and Klebsiella spp izolatlarını tanımlamak

Yöntemler: Nepal Pokhara'da yer alan Manipal Eğitim Hastanesi'nde hastaların çeşitli klinik örneklerinden izole edilen E. coli and Klebsiella spp. suşlarında GSBL sıklığını belirlemek için Ekim 2011 ve Nisan 2012 arasında kesitsel bir çalışma yapıldı. GSBL üretimi "Clinical laboratory Standards Institute" (CLSI) önerilerine gore belirlendi.

Bulgular: Çeşitli klinik örneklerden izole edilen 285 E. coli ve 55 Klebsiella spp $(n=55, \% 16,2)$ çalışmaya dahil edildi. Örnekler in 255'i (\% 75) idrar, 18'i $(\% 5,3)$ kan, 48'i $(\%$ 14,1) püy, 17'si (\% 5,1) balgam ve 2'si (\% 0,6) vücut sıvısı idi. Çift disk difüzyon ile yapılan fenotipik konfirmasyon testine göre 76 (\% 22.4) izolat GSBL üretiyordu. GSBL üreten mikroorganizmaların hepsi (\% 100) ampisilin ve seftriaksona dirençli idi. Çalışmaya dahil edilen izolatların \% 100'ü karbapenemlere, \% 95,6'sı ise sefaperazon-sulbaktama duyarlı idi. GSBL üreten izolatlar siprofloksasin (\% 90,7), seftriakson (\% 89,4), seftazidim (\% 89,4), kotrimaksazol $(\% 90,4)$ ve norfloksasin $(\% 88,1)$ GSBL üretmeyen gruba göre daha yüksek oranda dirençli idiler.

Sonuç: Nepal'de GSBL üreten E. coli and Klebsiella spp. prevalansı yüksek bulundu. Nepal hastanelerinde antibiyotik tedavisinin optimize edilmesi ve GSBL üreten mikroorganizmaların yayılımının engellenmesi için laboratuarda rutin olarak GSBL belirlemeye yönelik testler uygulanmalıdır.

Anahtar kelimeler: Genişlemiş spektrumlu beta-laktamaz, GSBL, E. coli, Klebsiella spp., prevalans, Nepal 


\section{INTRODUCTION}

Beta-lactam drugs like penicillins, cephalosporins, carbapenems and aztreonam are common antibiotics used to combat most bacterial infections. Multiple factors are responsible for the emergence of antibiotics resistance such as their use, doses, and the clinical practices concerning isolation of patients infected with multidrug resistant pathogens. ${ }^{1}$ Increased use of broad spectrum antibiotics such as third generation cephalosporins has been co-related with the development of $\beta$-lactamases mediated bacterial resistance, which subsequently led to the emergence of Extended spectrum beta-lactamases (ESBLs) producing organisms. ${ }^{2}$

ESBLs are characterized as the $\beta$-lactamases that are capable of producing bacterial resistance to penicillin, extended spectrum cephalosporins and monobactams except cephamycins and carbapenems. Beta lactamase inhibitors like clavulanic acid inhibits ESBLs. ${ }^{3}$

At present, more than 200 ESBLs have been characterized. ${ }^{3}$ Members of Enterobacteriaceae, especially Klebsiella spp that produce ESBL have been established since 1980s. Several community acquired pathogens like Escherichia coli, Salmonella, Shigella and Vibrio cholera which are often the causative agents of urinary tract infections and diarrhea were ESBL producers. ${ }^{4}$ ESBLS are commonly encoded by genes present on large plasmids. The plasmids also carry genes responsible for resistance to other antibiotics for example, aminoglycosides, trimethoprim, sulphonamides, tetracycline and chloramphenicol. ${ }^{5}$ As a result, only few antibiotics are available to combat ESBL producers. Carbapenems are efficient against serious infections caused by ESBL producing organisms so far. However, carbapenem resistant organisms have been reported in recent years. ${ }^{6}$

ESBL producers are the important members of the group of antibiotic resistant pathogens that cause hospital acquired infections. Significant proportion of laboratories in Nepal does not perform tests to detect ESBL producers. Therefore, this issue is of particular concern that poses a great challenge to every laboratory as the proportion of ESBL producing Enterobacteriaceae members are growing worldwide.

Present study reveals the prevalence of $E$. coli and Klebsiella spp producing ESBL in Manipal Teaching Hospital, Pokhara, Nepal.

\section{METHODS}

\section{Clinical isolates}

All E. coli and Klebsiella spp isolated from various clinical specimens (urine, blood, pus, sputum and body fluids) in Manipal Teaching Hospital within six months (October 2011 to April 2012) were studied. A data sheet was prepared for each patient from whom these isolates were obtained. The data sheet included age, gender, type of specimen, ward along with antibiotic profile of the isolates. Total number of organisms in this study was 340 and each sample refers to each participants.

Bacterial isolates were identified by conventional microbiological methods ${ }^{7}$ based on colony character in MacConkey Agar plates and biochemical characteristics of the organisms shown in different media and tests.

\section{Antibiotic sensitivity test}

Kirby Bauer disk diffusion method was used to test the antibiotic sensitivity following Clinical laboratory Standards Institute (CLSI) guidelines. ${ }^{8}$ Antibiotics used for all the clinical isolates were ampicillin (10 $\mu \mathrm{g})$, cefotaxime $(30 \mu \mathrm{g})$, ceftriaxone $(30 \mu \mathrm{g})$, ceftazidime $(30 \mu \mathrm{g})$, amikacin $(30 \mu \mathrm{g})$, gentamicin $(10 \mu \mathrm{g})$, ciprofloxacin $(5 \mu \mathrm{g})$, netilmicin $(30 \mu \mathrm{g})$, and imipenem $(10 \mu \mathrm{g})$.

\section{Screening test for ESBLs}

According to CLSI guidelines, ${ }^{8}$ organisms (E. coli and Klebsiella spp) that show inhibition zone of $\leq 22$ $\mathrm{mm}$ with ceftazidime $(30 \mu \mathrm{g})$, or $\leq 25 \mathrm{~mm}$ with ceftriaxone $(30 \mu \mathrm{g})$, or $\leq 27 \mathrm{~mm}$ with cefotaxime $(30 \mu \mathrm{g})$ in Mueller Hinton Agar (MHA) were recognized as potential ESBL producing organisms and further screened by determining minimum inhibitory concentration (MIC) of the same three antibiotics individually by Agar dilution procedure.

The isolates ( $E$. coli, K. pneumoniae and $K$. oxytoca) growing with MIC $\geq 2 \mu \mathrm{g} / \mathrm{ml}$ of the antibiotics (Ceftazidime, Cefotaxime, or Ceftriaxone) may indicate ESBL production. ${ }^{8}$ Control strain used for all these tests and procedure was E. coli NCTC 10418.

\section{Confirmatory test for ESBLs}

\section{Phenotypic confirmatory test}

Disks of third generation cephalosporins alone and disks of third generation cephalosporins plus clavulanic acid are required for this test. 
Ceftazidime $(30 \mu \mathrm{g})$ disk alone and ceftazidime + clavulanic acid $(30 \mu \mathrm{g}+10 \mu \mathrm{g})$ disk; and cefotaxime $(30 \mu \mathrm{g})$ disk alone and cefotaxime + clavulanic acid $(30 \mu \mathrm{g}+10 \mu \mathrm{g})$ disk were used in this study. The disks were placed at a distance of at least $25 \mathrm{~mm}$ on a carpet culture of the isolate on MHA plate. Differences in zone diameters of cephalosporins alone and in combination with clavulanic acid were recorded after incubation for 16-18 hours at $37^{\circ} \mathrm{C}$.

Interpretation: $\geq 5 \mathrm{~mm}$ increase in zone diameter around cephalosporin plus clavulanic acid disk compared to cephalosporin alone indicates ESBL production by the organism.

\section{Statistical Analysis}

Data from the case record forms were entered in the worksheet of Statistical Package for Social Science (SPSS) software of version 21.0. Frequency and percentages were analyzed as descriptive findings. Inferential statistics were analyzed using Chi square to see the association between the dependent variable (ESBL and non-ESBL) and the independent variables (e.g. age, gender, sources of sample, samples and organisms).

Ethical clearance was received from the Research Committee in Manipal Teaching Hospital, Pokhara. Sample from the participants were only included in the study after the verbal consent was taken from each one of them. Any refusal to contribute the sample was well respected. Anonymity of the participants was secured by coding each participants sample before the data analysis.

\section{RESULTS}

Total number of the clinical isolates in this study was 340 . E. coli $(\mathrm{n}=285,83.8 \%)$ and Klebsiella spp $(n=55,16.2 \%)$ were recovered from different clinical specimens. The specimens were urine $255(75 \%)$, pus $48(14.1 \%)$, blood $18(5.3 \%)$, sputum $17(5.1 \%)$ and body fluid $2(0.6 \%)$. The largest number of samples were received from different wards $(49.7 \%)$, followed by emergency room (ER) $(27.4 \%)$, different outpatient departments (OPD) $(13.8 \%)$, intensive care unit (ICU) (8.2\%) and post-operative ward $(0.9 \%)$ (Table 1$)$.

Out of 340 total organisms (E. coli and Klebsiella spp) 120 showed resistances to one or two or all three antibiotics. Both ceftazidime $(30 \mu \mathrm{g})$ and ceftriaxone $(30 \mu \mathrm{g})$ detected $89.4 \%$ of ESBL producers when used alone, while cefotaxime $(30 \mu \mathrm{g})$ detected $100 \%$ of ESBL producers when used alone.

Among 120 organisms, 76 were confirmed as ESBL organisms by phenotypic confirmatory test with double disk diffusion method. Out of 76 ESBL producers, number of $E$. coli was $62(18.2 \%)$ and Klebsiella spp was 14 (4.1\%). Highest number of ESBL organisms was isolated from urine, accounting for $78.9 \%$ of all ESBL positive isolates recovered (Table 1).

Table 1. Socio-demographic characteristics of the participants $(n=340)$

\begin{tabular}{|c|c|c|}
\hline Characteristics & $\begin{array}{c}\text { Number } \\
\text { (n) }\end{array}$ & $\begin{array}{c}\text { Percentage } \\
(\%)\end{array}$ \\
\hline \multicolumn{3}{|l|}{ Age in years } \\
\hline$\leq 20$ Years & 73 & 21.5 \\
\hline 21 - 40 Years & 99 & 29.1 \\
\hline $41-60$ Years & 68 & 20 \\
\hline 61 - 80 Years & 80 & 23.5 \\
\hline$\geq 81$ Years & 20 & 5.9 \\
\hline \multicolumn{3}{|c|}{ Mean $=42.55$, Median $=40.00$} \\
\hline \multicolumn{3}{|c|}{ SD $=25.34$, Skewness $=0.013$} \\
\hline \multicolumn{3}{|c|}{ Range $=0.003-91$ years } \\
\hline \multicolumn{3}{|l|}{ Sex } \\
\hline Male & 140 & 41.2 \\
\hline Female & 200 & 58.8 \\
\hline \multicolumn{3}{|l|}{ Source of samples } \\
\hline Ward & 169 & 49.7 \\
\hline OPD & 47 & 13.8 \\
\hline ER & 93 & 27.4 \\
\hline ICUs & 28 & 8.2 \\
\hline Post Op & 3 & 0.9 \\
\hline \multicolumn{3}{|l|}{ Sample } \\
\hline Urine & 255 & 75 \\
\hline Blood & 18 & 5.3 \\
\hline Pus & 48 & 14.1 \\
\hline Sputum & 17 & 5.1 \\
\hline Body Fluid & 2 & 0.6 \\
\hline \multicolumn{3}{|l|}{ Isolated organism } \\
\hline E. coli & 285 & 83.8 \\
\hline Klebsiella spp & 55 & 16.2 \\
\hline
\end{tabular}

\section{Antimicrobial susceptibility pattern}

ESBL group of organisms were found to be $100 \%$ resistant to ampicillin and cefotaxime. All the organisms in this study were $100 \%$ sensitive to imipenem and $95.6 \%$ sensitive to cefoperazone+sulbactam (Table 2). 
ESBL group showed increased resistance to ciprofloxacin, ceftriaxone, ceftazidime, cefazolin, cotrimoxazole, norfloxacin, netilmicin, gentamicin, amikacin and nitrofurantoin as compared to non
ESBL group. ESBL producing organisms showed significantly higher multidrug resistance than non ESBL producing organisms. (Table 2)

Table 2. Antibiotic profile of isolates in relation to ESBL $(n=340)$

\begin{tabular}{|c|c|c|c|c|}
\hline Characteristics & Number (\%) & ESBL (\%) & Non-ESBL (\%) & $p$-value \\
\hline \multicolumn{5}{|l|}{ Ampicillin } \\
\hline Sensitive & $60(17.6)$ & $0(0)$ & $60(100)$ & \multirow[t]{2}{*}{$<0.001$} \\
\hline Resistant & $280(82.4)$ & $76(27.1)$ & $204(72.9)$ & \\
\hline \multicolumn{5}{|l|}{ Ciprofloxacin } \\
\hline Sensitive & 119(35) & $7(5.8)$ & 113(94.2) & \multirow{2}{*}{$<0.001$} \\
\hline Resistant & $221(65)$ & $69(31.4)$ & $151(68.6)$ & \\
\hline \multicolumn{5}{|l|}{ Gentamicin } \\
\hline Sensitive & 234(68.8) & $28(12.0)$ & 206(88.0) & \multirow[t]{2}{*}{$<0.001$} \\
\hline Resistant & 106(31.2) & $48(45.3)$ & $58(54.7)$ & \\
\hline \multicolumn{5}{|l|}{ Cefazolin } \\
\hline Sensitive & $57(16.8)$ & $0(0)$ & $57(100)$ & \multirow[t]{3}{*}{$<0.001$} \\
\hline Resistant & $195(57.4)$ & $60(30.8)$ & $135(69.2)$ & \\
\hline Not tested & $88(25.9)$ & $16(18.2)$ & $72(81.8)$ & \\
\hline \multicolumn{5}{|l|}{ Netilmicin } \\
\hline Sensitive & $245(72.1)$ & $26(10.7)$ & 218(89.3) & \multirow[t]{2}{*}{$<0.001$} \\
\hline Resistant & $95(27.9)$ & $50(52.6)$ & $45(47.4)$ & \\
\hline \multicolumn{5}{|l|}{ Cotrimoxazole } \\
\hline Sensitive & 108(31.8) & $6(5.6)$ & $102(94.4)$ & \multirow[t]{3}{*}{$<0.001$} \\
\hline Resistant & 169(49.7) & $57(33.7)$ & $112(66.3)$ & \\
\hline Not tested & $63(18.5)$ & $13(20.6)$ & $50(79.4)$ & \\
\hline \multicolumn{5}{|l|}{ Norfloxacin } \\
\hline Sensitive & $93(27.4)$ & $7(7.5)$ & $86(92.5)$ & \multirow[t]{3}{*}{$<0.001$} \\
\hline Resistant & $159(46.8)$ & $52(32.7)$ & $107(67.3)$ & \\
\hline Not tested & $88(25.9)$ & $17(19.3)$ & 71(80.7) & \\
\hline \multicolumn{5}{|l|}{ Nitrofurantoin } \\
\hline Sensitive & $248(72.9)$ & $52(21.0)$ & 196(79.0) & \multirow[t]{3}{*}{0.067} \\
\hline Resistant & $76(22.4)$ & $23(30.3)$ & $53(69.7)$ & \\
\hline Not tested & $16(4.7)$ & $1(6.3)$ & $15(93.8)$ & \\
\hline \multicolumn{5}{|c|}{ Cefoperazone-Sulbactam } \\
\hline Sensitive & $325(95.6)$ & $61(18.8)$ & $264(81.2)$ & \multirow[t]{2}{*}{$<0.001$} \\
\hline Resistant & $15(4.4)$ & $15(100)$ & $0(0)$ & \\
\hline \multicolumn{5}{|l|}{ Amoxiclav } \\
\hline Sensitive & $7(2.1)$ & $1(14.3)$ & $6(85.7)$ & \multirow[t]{3}{*}{0.705} \\
\hline Resistant & $54(15.9)$ & 14(25.9) & $40(74.1)$ & \\
\hline Not tested & $279(82.1)$ & 61(21.9) & $218(78.1)$ & \\
\hline \multicolumn{5}{|l|}{ Amikacin } \\
\hline Sensitive & $257(75.6)$ & $29(11.3)$ & 228(88.7) & \multirow[t]{2}{*}{$<0.001$} \\
\hline Resistant & $83(24.4)$ & $47(56.6)$ & $36(43.4)$ & \\
\hline \multicolumn{5}{|l|}{ Ceftazidime } \\
\hline Sensitive & 235(69.1) & $8(3.4)$ & $227(96.6)$ & $<0.001$ \\
\hline Resistant & $105(30.9)$ & $68(64.8)$ & $37(35.2)$ & \\
\hline Ceftriaxone & & & & \\
\hline Sensitive & $233(68.5)$ & $8(3.4)$ & $225(96.6)$ & $<0.001$ \\
\hline Resistant & 107(31.5) & $68(63.6)$ & $39(36.4)$ & \\
\hline Cefotaxime & & & & \\
\hline Sensitive & $222(65.3)$ & $0(0)$ & $222(100)$ & $<0.001$ \\
\hline Resistant & $118(34.7)$ & $76(64.4)$ & $42(35.6)$ & \\
\hline
\end{tabular}


Potential ESBL producing organisms can be screened by either simple disk diffusion tests (DDT) with different third generation cephalosporins or by determining MIC of the same antibiotics. Cefotaxime was found to be more reliable drug to detect poten- tial ESBL producers by both methods. Among two methods, Kirby Bauer disk diffusion method is more sensitive to detect potential ESBL producers. However, determination of MIC method is more specific in detecting potential ESBL producers. (Table 3)
Table 3. Comparison of screening tests (Minimal inhibitory concentration= MIC; and Double Disk Diffusion Test=DDDT)

\begin{tabular}{lcccc}
\hline & \multicolumn{2}{c}{ Non-ESBL } & \multicolumn{2}{c}{ Potential ESBL producers } \\
\hline Antibiotic & MIC & DDT & MIC & DDT \\
Ceftazidime & $14(11.6 \%)$ & $3(2.5 \%)$ & $106(88.3 \%)$ & $117(97.5 \%)$ \\
Ceftriaxone & $13(10.9 \%)$ & $8(6.7 \%)$ & $107(89.1 \%)$ & $112(93.3 \%)$ \\
Cefotaxime & $11(9.2 \%)$ & $2(1.7 \%)$ & $109(90.8 \%)$ & $118(98.3 \%)$ \\
\hline
\end{tabular}

The phenotypic confirmation of ESBL positive bacteria were done by Double Disk Diffusion Test (DDDT) with two combinations, 1) ceftazidime (CAZ) alone and ceftazidime plus clavulanic acid (CAC) and, 2) cefotaxime (CTX) alone and cefotaxime plus clavulanic acid (CEC). Seventy six (22.4\%) isolates showed ESBL positive by both combinations (CAZ+CAC, and CTX+CEC). (Table 4)

Table 4. Detection of ESBL by Double Disk Diffusion test as confirmatory test

\begin{tabular}{llll}
\hline Organism & CAZ, CAC & CTX, CEC & Both \\
\hline E. coli & $65(19.1 \%)$ & $63(18.5 \%)$ & $62(18.2 \%)$ \\
Klebsiella spp & $14(4.1 \%)$ & $15(4.4 \%)$ & $14(4.1 \%)$ \\
\hline Total & $79(23.2 \%)$ & $78(22.9 \%)$ & $76(22.4 \%)$ \\
\hline
\end{tabular}

Ceftazidime (CAZ), ceftazidime plus clavulanic acid (CAC)

Cefotaxime (CTX), cefotaxime plus clavulanic acid (CEC)

\section{DISCUSSION}

The incidence of ESBL organisms varies significantly all over the world. In this study, majority of the organisms were isolated from urine $(75 \%)$ where $E$. coli is the major ESBL producer (18.2\%). The major source of ESBL producers were respiratory tract samples in another study and the highest ESBL production was observed in Klebsiella spp (67.04\%). ${ }^{9}$ However, Arif Maqsood Ali found Enterobacter cloacae $(76 \%)$ as the most frequent ESBL producer. ${ }^{10}$ A study on ESBL organisms, causing UTI, E. coli (64.0\%) followed by Klebsiella spp (17.9\%) were found as the most common organisms. ${ }^{11}$

The prevalence of ESBL producers is $22.4 \%$ in this study. Findings from other studies in Nepal have shown ESBL production ranging from 18\% to $62.7 \% .{ }^{11-13}$ Variation might have occurred due to low number of samples studied. Similiarly, variation in prevalence of ESBL producing organisms were found in other countries. ${ }^{14-23}$ Significant increase in ESBL organisms were published from India, ${ }^{14-18}$ Pakistan, ${ }^{19,20}$ Nigeria, ${ }^{21}$ Hong Kong ${ }^{22}$ and Germany. ${ }^{23}$

During a six years period (1997-2002), prevalence of ESBL producing Klebsiella spp were reported from Latin America (42.7\%), Europe (21.7\%) and North America (5.8\%). ${ }^{24}$ In USA, Enterobacteriaceae producing $\mathrm{ESBL}$ ranged between $0-25 \%$ in different institutions, while the national average was around $3 \%{ }^{25}$ Strict antibiotic policies might be the reason for lower rate of ESBL organisms in Europe and America.

In the present study, all organisms confirmed as ESBL producers by phenotypic confirmatory tests showed resistant to cefotaxime. The sensitivity of both ceftazidime and ceftriaxone to detect ESBL production was $89.4 \%$. In Hong Kong, the sensitivity of different extended spectrum $\beta$-lactam drugs was studied. The study found cefotaxime as $100 \%$ sensitive to indicate ESBL activity. ${ }^{22}$ Paudyal et al found cefotaxime as the reliable screening agent for ESBL detection with sensitivity and positive predictive value of $98.6 \%$ and $76.4 \%$ respectively..$^{13}$ This finding is consistent with a study in India which found ESBL producers resistant to cefotaxime, ceftriaxone and ceftazidime by $87.5 \%, 83.7 \%$ and $81.2 \%$ respectively. ${ }^{14}$ This implies that cefotaxime $(30 \mu \mathrm{g})$ can be the drug of choice to screen out ESBL producers.

Present study showed the co-resistance of ESBL producers to different antibiotics such as ciprofloxacin (90.7\%), gentamicin $(63.1 \%)$, amikacin $(61.8 \%)$ and cotrimoxazole $(90.4 \%)$. This type of co-resistance was consistent with the studies in Australia ${ }^{26}$ and Pakistan. ${ }^{27}$ Moreover, all the organisms were $100 \%$ sensitive to imipenem and $95.6 \%$ sensitive to cefoperazone + sulbactam. The $4.4 \%$ 
of isolates which showed resistance to cefoperazone + sulbactam might be because of AmpC type of $\beta$-lactamase and ESBL production. This finding is consistent with the study by Thakur et al in $\mathrm{Ne}$ pal where all organisms were sensitive to imipenem $(100 \%)$ followed by meropenem $(94.4 \%) .{ }^{11}$ In another study by S. Sharma et al, gram negative bacteria were tested against different antibiotic combinations. Among all combinations with $\beta$-lactam inhibitor, the most effective combination against ESBL organisms was cefepime plus tazobactum. ${ }^{18}$ Future studies should explore the role of different combinations as alternative drugs to carbapenems in order to treat ESBL infections effectively.

Numerous studies have reiterated the importance of antibacterial agents and their rational use. In addition, effective infection management measures and the need of newer antibiotics are to be proiritized. ${ }^{28}$ At present, development of resistance by bacteria has been the biggest challenge. ${ }^{29}$ The challenge of producing newer antibiotics in next 5-10 years to keep up with emerging multi drug resistant infections could rise. Enhanced infection control strategies, along with the rational use of antibiotics could be important factors to reduce the spread of ESBL producers.

Carbapenems are established as drug of choice for ESBL infections. People in developing countries like Nepal can hardly afford this treatment. Moreover, this is the reserved group of antibiotics which should be used very rationally. There has been recent evidence of selection for carbapenem resistant organisms. ${ }^{6}$

\section{Limitation}

Although utmost sincerity and dedication was invested to carry out the study it could not go beyond some limitations. Molecular studies for detection of various classes of ESBL were not included in this study. The factors leading to co-resistance with other antibiotics were not studied. No analysis was done to differentiate different types of ESBL and their clinical significance.

\section{CONCLUSION}

E. coli and Klebsiella spp showed the major prevalence of ESBL production in Manipal Teaching Hospital. Phenotypic confirmatory test with double disk diffusion method is simple and economical to detect ESBL producers. Standard ESBL detection method is required in laboratory which can direct the appropriate antibiotics for the treatment.
Studies from various parts of the country are mandatory to conclude the overall prevalence of ESBL producing pathogens. In addition, molecular level study is essential to identify the type of ESBL organisms that are prevalent in a given setting.

\section{Acknowledgement}

I would like to thank all staffs in the laboratory and the participants in this study. No fund was available for this study.

\section{REFERENCES}

1. Livermore DM. Bacterial resistance: Origin, Epidemiology and Impacts. Clin Infect Dis 2003;36(Suppl 1)S11-23.

2. Finch RG. Antibiotic resistance. J Antimicrob Therap 1998;42:125-128.

3. Livermore DM. Current epidemiology and growing resistance of gram negative pathogens. Korean J Intern Med 2012;27:128-142.

4. Poirel L, Gniadkowski M, Nordmann P. Biochemical analysis of the ceftazidime hydrolyzing extended spectrum $\beta$-lactamase CTX-M 15 and of its structurally related $\beta$-lactamase CTX-M 3. J Antimicrob Chemother 2002;50:1031-1034.

5. Paterson DL. Recommendation for treatment of severe infections caused by Enterobacteriaceae producing extended spectrum $\beta$-lactamases (ESBLs). Clin Microbiol Infect 2000:460-463.

6. Queenan AM, Bush K. Carbapenemases: the versatile B-lactamases. Clin Microbiol Rev 2007;20:440-458.

7. Koneman EW, Allen SD, Janda WM, et al. The enterobacteriaceae. In Color Atlas and textbook of diagnostic microbiology, 5th edition. JB Lippincott Co: Philladelphia; 2006;211-302.

8. Clinical and Laboratory Standards Institute. Performance standards for antimicrobial susceptibility testing; twenty-first informational supplement. M100-S21 2011;31:42-46.

9. Sharma M, Pathak S, Srivastava P. Prevalence and antibiogram of Extended Spectrum $\beta$-Lactamase (ESBL) producing Gram negative bacilli and further molecular characterization of ESBL producing Escherichia coli and Klebsiella spp. J Clin Diagn Res 2013;7:2173-2177.

10. Ali AM, Rafi S, Qureshi AH, et al. Frequency of Extended Spectrum $\beta$-Lactamases (ESBL) producing nosocomial isolates in a tertiary care hospital in Rawalpindi. Pak Armed Forces Med J 2009(03). http://pafmj.org/showdetails. php?id=241\&t=o.

11. Thakur S, Pokhrel N, Sharma M. Prevalence of Multidrug Resistant Enterobacteriaceae and Extended Spectrum $\beta$-Lactamase Producing E. coli in Urinary Tract Infection. Res J Pharm Biol Chem Sci 2013;4:1615-1624.

12. Shrestha $S$, Amatya R, Dutta R. Prevalence of extended spectrum $\beta$-lactamase (ESBL) production in gram negative isolates from pyogenic infection in tertiary care hospital of eastern Nepal. Nepal Med Coll J 2011;13:186-189.

13. Poudyal S, Bhatta DR, Shakya G, et al. ESBL producing multi drug resistant clinical bacterial isolates at NPHL, Nepal. Nepal Med Coll J 2011; 13:34-38.

14. Agrawal $P$, Ghosh AN, Kumar S, et al. Prevalence of extended spectrum $\beta$-lactamases among $E$. coli and K. pneumoniae isolates in a tertiary care hospital. Indian J Pathol Microbiol 2008;51:139-142. 
15. Babypadmini S, Appalaraju B. Extended spectrum $\beta$-lactamases in urinary isolates of E.coli and K. pneumoniae: Prevalence and susceptibility pattern in a tertiary care hospital. Indian J Med Microbiol 2004;22:172-174.

16. Shivaprakasha S, Radhakrishnan K, Gireesh A, et al. Routine screening for ESBL Production, A necessity of Today. The Internet J Microb 2006;3:1.

17. Sasirekha B, Manasa R, Ramya $P$, et al. Frequency and Antimicrobial Sensitivity Pattern Of Extended Spectrum $\beta$-Lactamases Producing E. coli and K. pneumoniae Isolated In A Tertiary Care Hospital. Al Ameen J Med Sci 2010;3:265271.

18. Sharma S, Gupta A, Arora A. Cefepime Tazobactam: A new $\beta$-lactam/ $\beta$-lactamase inhibitor combination against ESBL producing gram negative bacilli. Int $\mathrm{J}$ Pharm Biomed Sci 2012;3:35-38.

19. Ali AM, Rafi S, Qureshi AH. Frequency of extended spectrum $\beta$-lactamase producing gram negative bacilli among clinical isolates at clinical laboratories of Army Medical College, Rawalpindi. J Ayub Med Coll Abbottabad 2004;16:35-37.

20. Ullah F, Malik SA, Ahmed J. Antimicrobial susceptibility pattern and $\mathrm{ESBL}$ prevalence in $\mathrm{K}$. pneumoniae from urinary tract infections in the North West of Pakistan. Afr J Microbiol Res 2009;3:676-680.

21. Yusha'u M, Aliyu HM, Kamurya AS, et al. Prevalence of Extended spectrum $\beta$-lactamases among Enterobacteriaceae in Murtala Mohammed Specialist Hospital, Kano, Nigeria. Bayero Journal of Pure and Applied Sciences 2010;3:169172.
22. Ho PL, Tsang DN, Que TL, et al. Comparison of screening methods for detection of extended spectrum $\beta$-lactamases and their prevalence among $E$. coli and Klebsiella spp in Hong Kong. APMIS 2000;108:237-240.

23. Wiegand I, Geiss HK, Mack D, et al. Detection of Extended Spectrum $\beta$-Lactamases among Enterobacteriaceae by use of semi-automated Microbiology Systems and Manual Detection Procedures. J Clin Microbiol 2007;45:1167-1174.

24. Biedenbach DJ, Moet GJ, Jones RN. Occurrence and antimicrobial resistance pattern comparisons among bloodstream infection isolates from the SENTRY Antimicrobial Surveillance Program (1997-2002). Diagn Microbiol Infect Dis 2004;50:59-69.

25. CDC National Nosocomial Infections Surveillance. 2010. Available from: http://www.cdc.gov/ncidod/hip/surveill/nnis. htm

26. Denholm JT, Huysmans M, Spelman D. Community acquisition of ESBL producing E. coli: a growing concern. Med J Aust 2009;190:45-46.

27. Jabeen K, Zafar A, Hasan R. Frequency and sensitivity pattern of extended spectrum $\beta$-lactamase producing isolates in a tertiary care hospital laboratory of Pakistan. J Pak Med Assoc 2005;55:436-439.

28. Paterson DL, Bonomo RA. Extended Spectrum $\beta$-Lactamases: a Clinical Update. Clin Microbiol Rev 2005;18:657-686.

29. Ghatole M, Manthalkar P, Kandle S, et al. Correlation of extended spectrum $\beta$-lactamases production with cephalosporin resistance in gram negative bacilli. Indian J Pathol Microbiol 2004;47:82-84. 